\title{
Cardiovascular risk rate in hypertensive patients attended in primary health care units: the influence of pharmaceutical care
}

\author{
Paulo Yuri Milen Firmino, ${ }^{1,3, *}$, Tainá Osterno Vasconcelos ${ }^{3}$, Caroline Carneiro Ferreira ${ }^{3}$, Larissa \\ Mendonça Moreira ${ }^{3}$, Nirla Rodrigues Romero ${ }^{2,3}$, Lilian Araújo Dias ${ }^{5}$, Maria Goretti Rodrigues de \\ Queiroz ${ }^{4}$, Marcos Venícios de Oliveira Lopes ${ }^{6}$, Marta Maria de França Fonteles ${ }^{1,2,3}$
}

\author{
${ }^{1}$ Graduate Program of Pharmaceutical Sciences, Federal University of Ceará, Fortaleza, CE, Brazil, ${ }^{2}$ Pharmacy Department, \\ Federal University of Ceará, Fortaleza, CE, Brazil, ${ }^{3}$ Pharmaceutical Care Study Center, Fortaleza, CE, Brazil, ${ }^{4}$ Clinical \\ and Toxicological Analysis Department, Federal University of Ceará, Fortaleza, CE, Brazil, ${ }^{5}$ Primary Healthcare Unit Dr. \\ Anastácio Magalhães, Fortaleza, CE, Brazil, ${ }^{6}$ Nursing School Department, Federal University of Ceará, Fortaleza, CE, Brazil
}

\begin{abstract}
Cardiovascular complications are relevant due to their frequency and severity on the hypertension scenario. Studies refer Pharmaceutical Care (PC) as capable of decreasing cardiovascular risk rate (\%CVR) on hypertensive patients. This study aimed to investigate, through a randomized clinical assay, the influence of PC service on the \%CVR of hypertensive patients assisted in a health primary care unit from Fortaleza-Ceará. Two study groups were formed: i. Intervention Group (IG), which received orientation about taking medicines, actions aiming to prevent/solve medicine interactions and adverse effects and non-pharmacological interventions for 9 months and, ii. Control Group (CG), which received traditional assistance of the unit and was monitored during the same period. It was observed a statistically significant reduction on \%CVR (10.76 to 7.86; $\mathrm{p}=0.04)$ and systolic blood pressure levels (SBP) (137.69 to $131.54 ; \mathrm{p}<0.01)$ in the IG, while, in the $\mathrm{CG}$, there was no significant alteration. 151 Drug Related Problem (DRP) were identified and it was realized 124 pharmaceutical interventions, with 89.2\% of them resulting on solution/prevention of the problem. Our findings indicated that the inclusion of the PC service in the hypertensive health assistance was more effective at the \%CVR and the SBP reduction in comparison to the traditional assistance offered.
\end{abstract}

Uniterms: Pharmaceutical care. Cardiovascular risk. Hypertension.

\begin{abstract}
As complicações cardiovasculares apresentam relevância devido à sua freqüência e gravidade no contexto da hipertensão. Estudos referem que a prestação do Cuidado Farmacêutico (CF) é capaz de reduzir a taxa de risco cardiovascular (\%RCV) em hipertensos. Esse trabalho objetivou investigar, com um ensaio clínico randomizado, a influência da prestação do $\mathrm{CF}$ na \% RCV em hipertensos atendidos em uma unidade de atenção primária à saúde de Fortaleza-Ceará. Formarm-se dois grupos de estudo: i. Grupo Intervenção (GI), que recebeu orientações sobre tomada dos medicamentos, ações visando prevenir/ resolver interações medicamentosas e reações adversas e intervenções não-farmacológicas por 9 meses e ii. Grupo Controle (GC), que recebeu assistência tradicional da unidade e foi monitorado durante o mesmo período. Observou-se redução estatisticamente significativa nas \%RCV $(10,76$ to 7,$86 ; \mathrm{p}=0,04)$ e nos níveis de pressão arterial sistólica (PAS) $(137,69$ to 131,$54 ; p<0,01)$ no GI, enquanto no GC, não houve alteração significativa. Identificaram-se 151 Problemas Relacionados com Medicamentos (PRM) e foram realizadas 124 intervenções farmacêuticas, das quais, 89,2\% resultaram em solução/prevenção dos problemas. Nossos achados indicaram que a inclusão do serviço de CF na assistência ao paciente hipertenso foi mais eficaz na redução da \%RCV e níveis de PAS em comparação à assistência tradicional.
\end{abstract}

Unitermos: Atenção Farmacêutica. Risco cardiovascular. Hipertensão.

\footnotetext{
*Correspondence: P. Y. M. Firmino. Programa de Pós-Graduação em Ciências Farmacêuticas. Universidade Federal do Ceará. Rua Carvalho Pereira, 175 - 60821-535 - Fortaleza - CE, Brasil. E-mail: yurifirmino@yahoo.com.br
} 


\section{INTRODUCTION}

Hypertension is a chronic disease characterized by a steady increase in blood pressure above normal rates, equal to or greater than $140 \mathrm{mmHg}$ and $90 \mathrm{mmHg}$ for the systolic and diastolic levels, respectively (Sociedade Brasileira de Cardiologia, 2010).

This is one of the largest causes of cardiovascular morbidity and mortality, being noticeably associated with the multifactorial etiology of ischemic heart disease, myocardial infarction, stroke alongside others cardiovascular events (Nobre, Coelho, 2013) and characterized as one of the biggest causes of reduced quality and life expectancy of individuals (Passos, Assis, Barreto, 2006).

In Brazil, according to DATASUS, it is estimated that there is a total of $16,934,611$ hypertensive people and that at least $10 \%$ of this total had a cardiovascular complication. Also, until the end of 2012, more than 78,345 hospitalizations were recorded with cases linked to essential hypertension (Brasil, 2013). The fact is that mortality in Brazil is still high compared to other countries, both for cerebrovascular disease and heart disease, complications known to be associated with hypertension (Brasil, 2009).

These facts draw attention to the importance of estimation of cardiovascular risk rate in hypertensive people. According to the VI Brazilian Guidelines on Hypertension (2010), the treatment strategy should be individualized according to the cardiovascular risk stratification as well as the goal of blood pressure level to be achieved. Therefore, strategies considering cardiovascular risk estimation and having its reduction as an ultimate outcome should be taken.

The Framingham Study has developed an estimate represented by the Framingham score, able to numerically predict the total risk of developing coronary artery disease which is used in several countries as a cardiovascular risk estimation tool (Mahmood et al., 2014). In Brazil, the Framingham risk scores estimate the absolute risk of coronary events in 10 years, generating points based on age, systolic and diastolic blood pressure, total cholesterol, HDL-cholesterol, smoking habit, and presence or absence of mellitus diabetes. After calculating the total points, the table of risks is taken into consideration for both sexes (Sociedade Brasileira de Cardiologia, 2013).

The role of the pharmacist as a health care provider for the general population and, in particular, for hypertensive patients, has been the subject of research worldwide. More than 70 randomized controlled trials published in English have reported this type of study (Roughead, Semple, Vitry, 2003; Aguiar et al., 2012), where the authors present clinical benefits associated with the provision of pharmaceutical care services and management of blood pressure control in hypertensive patients.

Some studies demonstrate the effectiveness of pharmaceutical care in dyslipidemia and the management of cardiovascular risk in hypertensive patients (Eizerik, Manfroi, 2008; Lyra Junior et al, 2011; Irons et al., 2012; Firmino et al., 2012), obtaining statistically significant results in the reduction of cholesterol levels, cardiovascular risk rate and blood pressure levels.

Despite that, the scarcity of studies conducted in the country considering the cardiovascular risk rate as an important outcome with a well-defined methodological design is still evident (Simoni, 2009; Ambiel, Mastroianni, 2013). This fact emphasizes the need for further scientific studies that assess the influence of pharmacotherapeutic monitoring in cardiovascular risk management in Brazil and collects epidemiological data in this context, particularly regarding the Northeast region of the country.

Thus, the present study aimed to evaluate the influence of pharmaceutical care on cardiovascular risk in hypertensive patients registered in a Pharmaceutical Care Unit (PCU) of a Primary Health Care Unit in Region III of Fortaleza, Ceará, comparing with the traditional health care offered routinely.

\section{MATERIAL AND METHODS}

\section{Type of study}

This was a randomized clinical trial inserted in a real scenario of the national primary care practice and characterized by a pharmacotherapeutic follow-up of patients with the duration of nine months, structured with a "control" group and an "intervention" group in parallel formed by patients with the same characteristics. The collecting of the patients was performed in the first four months of the period of the study (October, 2011 to September, 2012).

The "intervention" group received pharmacotherapeutic follow-up (PTF) performed by a pharmacist trained in pharmaceutical care practice, which was regarded as the intervention in question, in addition to traditional care performed in the pharmacy unit of Dr. Anastacio Magalhães Primary Health Care (UAPS-AM). During the referred PTF, activities in health education, detection, resolution and prevention of drug related problems (DRP), and monitoring of adherence to prescribed treatment were provided to the participants. In turn, the "control" group was only monitored by the researcher during the nine months aiming to collect data for future comparison with the "intervention" group. 
It is noteworthy that all activities relating to pharmaceutical care were made in the Pharmaceutical Care Unit (PCU) of UAPS-AM.

\section{Selection of patients}

The target patients were primarily those previously diagnosed with systemic hypertension who, in the first or subsequent appointments, had a) the existence of uncontrolled blood pressure and/or presence of cardiovascular risk factors, or b) difficult control and adherence problems to the treatment; or c) the need for education about the proposed pharmacotherapy and/or the use of two or more drugs for hypertension. These criteria were identified by the UAPS physicians, nurses and pharmacists of the dispensing pharmacy as well as by the team performing the present study after active dissemination of the study in the queues in the local pharmacy or in queues for medical appointments.

For this, the UAPS professionals were sensitized to this work, emphasizing the mechanisms for referral and counter-referral of patients. From established criteria, physicians, nurses and pharmacists could collaborate in the referral of patients to PCU.

The identified target patients were referred to the study team and then invited to participate, being led to the office designated for the PCU. In the office, the project was presented in more detail and the Free and Clarified Term of Consent (TC) was applied. After the acceptance and signature of the TC, the first interview scheduled by the researcher was started.

Those patients referred by health professionals, or invited by the performing team, who were not able to answer the questions of the pharmacotherapeutic record because of mobility or previously diagnosed mental disabilities, who had no conditions to attend the meetings when labeled, who reported participation in another intervention project in the same framework of this study were not enrolled. Those randomized to the intervention group who missed two consecutive meetings, resulting in four consecutive months of absence during follow-up were excluded.

This study did not use sample size calculation. The sample was formed by all patients of the UAPS who were referred to the PCU during the period established for patient enrollment in the present study.

\section{Randomization}

Both groups were determined by stratified randomization. All the participants were organized in subgroups according to sex and presence of cardiovascular risk factors such as Diabetes Mellitus, dyslipidemia and history of cardiovascular event. After that, four subgroups were formed (men without risk, men with risk, women without risk and women with risk) and each one was randomized with special care so that they remained as homogeneous as possible among themselves, in terms of size and characteristics, which could influence the final results.

The process was performed with the help of an unrelated person to the study. The toss of a coin was used as allocation mechanism with the unrelated person allocating the participants until the groups had the same number of patients from each subgroup. This process was concealed from the researcher of this study aiming to avoid bias in this specific procedure.

\section{Instruments used}

To implement the PTF the following instruments previously prepared by the staff members of the Center for Studies in Pharmaceutical Care (CEATENF), Federal University of Ceará (UFC), were used: an interview questionnaire, a development spreadsheet, an intervention planning worksheet, a timetable and a counter-reference tool. In addition to these instruments, the Framingham score table (Sociedade Brasileira de Cardiologia, 2013) was used to perform the calculation of cardiovascular risk of each patient included in the study by counting the points obtained in accordance with the parameters illustrated in that instrument. All these instruments were already being used in the service provided by PCU and were tested and optimized in a previous study (Firmino et al., 2012).

\section{Data collection}

The PTF was configured according to the Dáder method (Dáder, Hernández, Castro, 2014), as a method for clinical monitoring of patients with the follow-up type.

The primary outcome of the PTF was the cardiovascular risk rate. The influence of the PTF in this outcome was assessed from laboratory tests (glucose, total cholesterol and its fractions, and triglycerides) and blood pressure measurements, which, in turn, were used to calculate cardiovascular risk according to the Framingham score, performed at three time points: at the beginning of the PTF, after five months of follow-up and at the end of the study.

The results from laboratory tests as glycemia, total cholesterol, LDL, HDL and triglycerides and both systolic and diastolic blood pressure levels were considered as 
secondary outcomes of the PTF. The laboratory tests were performed by collaboration from the Toxicology and Clinical Analysis Laboratory (LACT), Federal University of Ceará, at the beginning of the PTF period, after five months and at the end. The blood pressure measurements were performed by the study team following the method described in the Brazilian Hypertension Guidelines (Sociedade Brasileira de Cardiologia, 2010).

Further data was collected through interviews performed during the PTF.

\section{Interviews}

The interviews with patients included in the study were performed by members of the PCU team in an office reserved for such purpose. The average interval between interviews was two months, with the first subsequent interview occurring one month later, and they were marked during the previous interview and confirmed by phone the day before to minimize absence to the scheduled meetings. Thus, six interviews were scheduled for each patient of the 'intervention' group.

The first one was reserved for the registration of the participant in the study, questionnaire completion and beginning of the PTF. All instruments were applied in this interview with the PCU team using all data collected to study each specific case, identifying DRP and elaborating interventions to solve or prevent them. During this interview the PCU team also provided general non-pharmacological information for hypertension control and cardiovascular risk factor management and corrected all evident adherence problems as well. These interviews averaged approximately 45 minutes and were carried out before randomization.

The subsequent interviews, called "return", served for the continuation of the PTF, when was performed the evaluation of the outcomes from previously suggested interventions, identification and resolution of new DRP and the update of information obtained in the first interview also checking if the patients were able to apply the non-pharmacological orientation provided. Whenever the patients presented an improvement towards their therapeutic goals, the PCU team notified them with the objective of giving a positive feedback. In the third and last interview, as a differential, the participants were referred to the Toxicology and Clinical Analysis Laboratory (LACT), Federal University of Ceará, for new laboratory tests. The returns had an average time around 15-20 minutes.

In the case of the "control" group, the data collection after the first interview was through occasional meetings (equivalent to those meetings where the participants from the other group were sent to LACT for new tests) where there was only monitoring of the variables, for later comparison with the "intervention" group. The "control" group patients were also sent for laboratory tests, similarly to other participating patients. Therefore, the "control" group received the traditional health care assistance offered in the Health Care Unit during the follow-up months. The performing team did not aim to identify DRP during these interviews but it is important to highlight that the PCU team notified other health professionals if patients from this group presented major health problems at the moment.

In each interview the measurement of blood pressure levels was conducted by the performing team on both group participants and after the interviews, the DRP identified were classified and certified by the CEATENF/ UFC technical group following the 2 nd Granada Consensus 2002 according to the referred study center routine, shown in Table I.

PCU was responsible for counter-reference, when appropriate. When the action to solve/prevent a DRP involved another health professional a brief written report was elaborated with the suggestion of pharmaceutical intervention and forwarded to the ones involved. Whenever possible the pharmaceutical intervention was discussed with the target of it in order to reach a consensus and ensure that it is applied and followed. It was ensured later if the intervention was accepted or not by the health professional involved or by the patient, if that was the case.

\section{Data analysis}

The groups were compared in relation to the results for the rate of cardiovascular risk, blood pressure levels and the relevant laboratory tests in its estimate.

The analysis of the results was performed after using the Statistic Package for Social Sciences (SPSS) 17.0 version for Windows, using the paired $t$ and McNemar tests for numerical and categorical variables, respectively. For all comparisons, a significance level of 5\% was considered.

\section{Ethical aspects}

The study was designed according to the guidelines and rules for research involving human subjects and it was approved by the Ethics Committee in Research of the Federal University of Ceará - COMEPE (protocol number: 228/11). 
TABLE I - Drug Related Problems classification (2nd Granada Consensus, 2002)

\begin{tabular}{ll}
\hline Classification & Description \\
\hline Necessity & $\begin{array}{l}\text { The patient suffers from a health problem as } \\
\text { a consequence of not receiving the medicine } \\
\text { that he needs. }\end{array}$ \\
\hline DRP 1 & $\begin{array}{l}\text { The patient suffers from a health problem as } \\
\text { a consequence of receiving a medicine that he } \\
\text { does not need. }\end{array}$ \\
DRP 2 & $\begin{array}{l}\text { The patient suffers from a health problem } \\
\text { as a consequence of a non-quantitative } \\
\text { ineffectiveness of the medication. }\end{array}$ \\
\hline DRP 3 & $\begin{array}{l}\text { The patient suffers from a health problem as a } \\
\text { consequence of a quantitative ineffectiveness } \\
\text { of the medication. }\end{array}$ \\
\hline DRP 4 & $\begin{array}{l}\text { The patient suffers from a health problem as } \\
\text { a consequence of a non-quantitative safety } \\
\text { problem of the medication. }\end{array}$ \\
\hline Safety & $\begin{array}{l}\text { The patient suffers from a health problem as a } \\
\text { of the medication. }\end{array}$ \\
\hline DRP 5 &
\end{tabular}

\section{RESULTS AND DISCUSSION}

From late October 2011 to late January 2012 hypertensive patients were invited to participate in the study.

Figure 1, above, shows the formation of the study sample from the beginning to the final group.

\section{General data of the population}

Table II shows the general characteristics of the study patients divided in two groups - "intervention" and "control" - in its baseline, also including relevant data to measure the rate of cardiovascular risk. The groups were considered homogeneous after due statistical tests.

\section{Control group versus intervention group}

An analysis of the differences obtained over the time in both groups ("control" group and "intervention" group), based on various clinical parameters, can be seen in Table III.

The "intervention" group presented a reduction in the Framingham score and the rate of cardiovascular

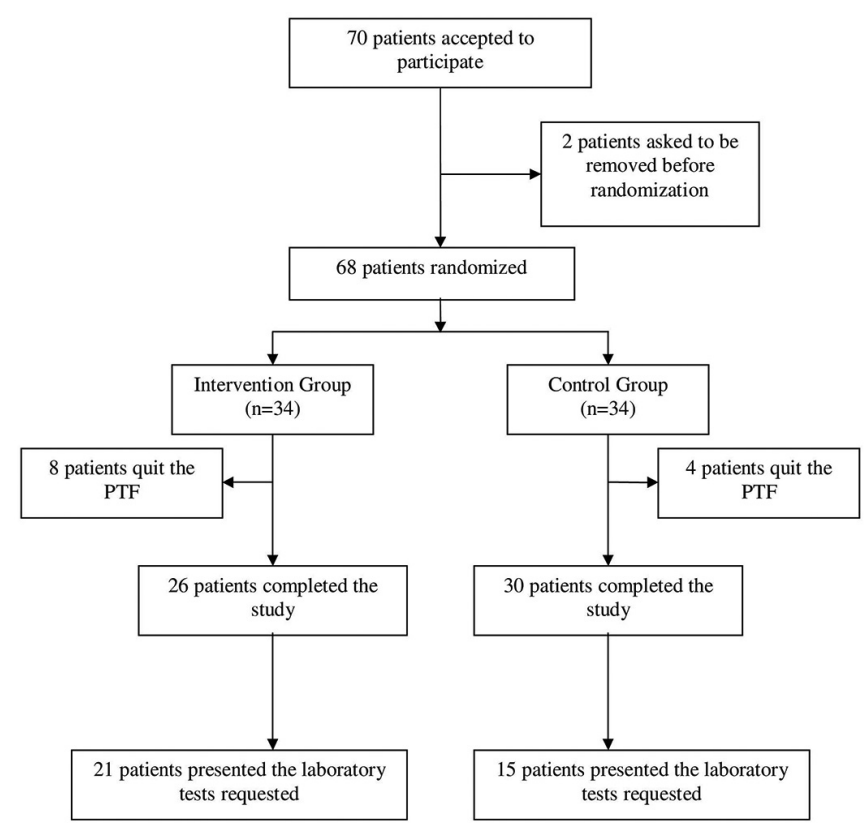

FIGURE 1 - Flowchart of the formation of the study sample (PCU-Anastácio Magalhães/October 2011 - September 2012).

risk calculated during the study (1.24 points and $2.9 \%$, respectively), showing a statistical difference ( $p<0.01$ in both cases). In turn, the" control" group did not show the same tendency to reduction of the average of these values.

When considering the parameters used for the cardiovascular risk evaluation, it was possible to observe some differences between the two study groups. Comparing the results of the pressure control of the groups, it was observed that the "intervention" group showed lower average in both systolic values (decrease of $6.16 \mathrm{mmHg}$ ) and the diastolic (decrease of $2.69 \mathrm{mmHg}$ ), observing statistically significant differences in systolic values ( $p=0.04)$, while the "control" group showed no significant change. Additionally, it was observed an increase in the number of patients with controlled systolic levels going from $46.2 \%(n=12)$ to $65.4 \%(n=17)$ in "intervention" group while in "control" group there was not a significant change in this number $(60 \%, n=18$ to $56.7 \%, \mathrm{n}=17)$.

In both groups, the serum levels of the total and LDL cholesterol tended to decrease after the study. However, the reduction of the former was higher in the "intervention" group, whereas the reduction of LDL levels was higher in the "control" group. The change in HDL was different among patients in the two study groups, that is, the "intervention" group had a slight increase in serum levels at the end of the study, while the "control" group showed minimal variation to below the observed initial average. Comparing the variations in triglyceride levels 
TABLE II - Baseline characteristics of the study participants from both study groups (PCU-Anastácio Magalhães/October 2011 September 2012)

\begin{tabular}{lccc}
\hline Variable (n;\%) & Control $(\mathrm{n}=34)$ & Intervention $(\mathrm{n}=34)$ & $P$ value \\
\hline Female gender & $26(76.5)$ & $26(76.5)$ & 1.00 \\
Mean age (years) & 60.7 & 59 & $0.48^{\#}$ \\
Diabetes Mellitus & $12(35.3)$ & $10(29.4)$ & 0.60 \\
Dyslipidemia & $16(47.1)$ & $17(50)$ & 0.81 \\
Patients who drink alcohol & $04(11.8)$ & $07(20.6)$ & 0.32 \\
Patients who are under diet & $21(61.8)$ & $22(64.7)$ & 0.80 \\
Previous cardiovascular event & $09(26.5)$ & $12(36.4)$ & 0.38 \\
Practice physical activity & $14(41.2)$ & $16(47.1)$ & 0.62 \\
Have a caretaker & $05(14.7)$ & $07(20.6)$ & 0.52 \\
Unlettered & 00 & $02(5.9)$ & 0.15 \\
Complete primary education & $07(20.6)$ & $05(14.7)$ & 0.52 \\
Complete secondary education & $09(26.5)$ & $16(47.1)$ & 0.08 \\
Complete major degree & $03(8.8)$ & $03(8.8)$ & 1.00 \\
Income $\leq 02$ minimum wage & $27(79.4)$ & $24(70.6)$ & 0.42 \\
Can buy in a drugstore & $24(70.6)$ & $28(82.4)$ & 0.25 \\
\hline
\end{tabular}

$P$ value determined by Chi-square test. ${ }^{*} \mathrm{t}$ test was performed.

TABLE III - Comparison of the results (mean) obtained in the study groups (total $\mathrm{n}=56$ ) at the end (PCU-Anastácio Magalhães/ October 2011 - September 2012)

\begin{tabular}{|c|c|c|c|c|c|c|}
\hline \multirow{2}{*}{ Variable } & \multicolumn{3}{|c|}{ Control $(n=30)$} & \multicolumn{3}{|c|}{ Intervention $(n=26)$} \\
\hline & $B L$ & 9 months & Pvalue & $B L$ & 9 months & Pvalue \\
\hline$\overline{\mathrm{SBP}(\mathrm{mmHg})}$ & 132 & 136.33 & 0.12 & 137.69 & 131.54 & $0.04^{\#}$ \\
\hline DBP (mmHg) & 79.67 & 83.67 & 0.06 & 81.92 & 79.23 & 0.11 \\
\hline Framingham Score (points)* & 15.93 & 16.26 & 0.35 & 15.67 & 14.42 & $<0.01^{\#}$ \\
\hline Cardiovascular Risk Rate (\%)* & 6.2 & 6.86 & 0.36 & 10.76 & 7.86 & $<0.01^{\#}$ \\
\hline Total Cholesterol $(\mathrm{mg} / \mathrm{dL})^{*}$ & 196 & 184.27 & 0.40 & 221.09 & 195.67 & 0.14 \\
\hline $\mathrm{LDL}(\mathrm{mg} / \mathrm{dL})^{*}$ & 120.6 & 109 & 0.34 & 127.03 & 122.24 & 0.54 \\
\hline $\mathrm{HDL}(\mathrm{mg} / \mathrm{dL})^{*}$ & 44.6 & 44.33 & 0.90 & 39.57 & 42.62 & 0.09 \\
\hline Triglycerides $(\mathrm{mg} / \mathrm{dL})^{*}$ & 153.67 & 161.73 & 0.57 & 248.76 & 204.43 & 0.35 \\
\hline Glycemia (mg/dL)* & 110.73 & 120.4 & 0.08 & 100.71 & 103.24 & 0.62 \\
\hline
\end{tabular}

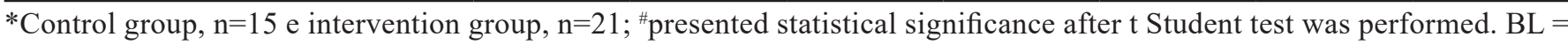
Baseline; SBP = Systolic Blood Pressure; DBP = Diastolic Blood Pressure.

observed in the study groups, it was observed that the "intervention" group had a reduction of the initial average after nine months of follow-up. Finally, it was observed in both groups an increase in the average of glycemia at the end of the PTF, although the difference between the initial and final mean value was more pronounced in the "control" group than in the "intervention" group.

The proportion of participants with controlled serum levels of these parameters changed as follows: the total cholesterol proportion decreased in the "intervention" group (61.9\% to 52.4\%) and increased in the "control" (53.3\% to $73.3 \%)$; the controlled LDL proportion passed from $20 \%$ to $35 \%$ in the group under PTF while the other group dropped from $46.7 \%$ to $40 \%$; it was observed a $10 \%$ increase on patients with at least $45 \mathrm{mg} / \mathrm{dL}$ of HDL after the nine months in the "intervention" group while there was no change in the other group proportion; patients with triglycerides at healthy levels represented $42.9 \%$ before 
the PTF e after it represented $57.1 \%$ of the group, the "control" group proportion also increased from $53.3 \%$ to $60 \%$; the proportions regarding glycemia remained the same on both groups.

\section{Drug related problems and pharmaceutical interventions}

A total of 151 DRP were detected and classified in the study population $(n=68)$. Among the DRP detected, the most frequent was ineffectiveness quantitative (DRP 04, $\mathrm{n}=48,31.8 \%$ ), followed by DRP 03, i.e. nonquantitative ineffectiveness of the medication $(n=43$, $28.5 \%$ ), DRP 05 , non-quantitative safety problem of the medication ( $\mathrm{n}=32,21.2 \%$ ), and DRP 01 , related to problems due to the non-use of necessary medication (n $=23,15.2 \%)$. Problems associated with overdose (DRP 06 ) and the use of unnecessary medications (DRP 02) were the least frequent (DRP 06: $\mathrm{n}=4,2.6 \%$; DRP 02: $\mathrm{n}=1$, $0.7 \%$ ), respectively (Figure 2 ).

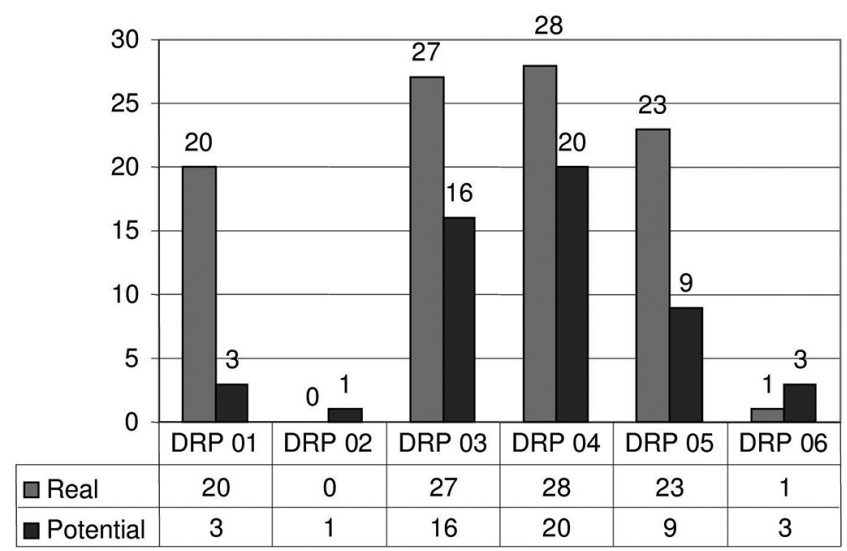

FIGURE 2 - Frequency of the DRP identified (2nd Granada Consensus), total=151 (PCU-Anastácio Magalhães/October 2011 - September 2012).

Regarding the type of DRP (whether potential or real), the most frequent one was real with $65.6 \%$ of incidence, equivalent to an $\mathrm{n}$ of 99 out of the whole 151 , with the potential type representing $34.4 \%(n=52)$.

Of the 151 DRP identified, there was a pharmaceutical intervention in $124(82.1 \%)$ - the patient / user accepted the proposed intervention in all cases. In $71 \%$ of them $(n=88)$ written information was delivered to the intervention target alongside verbal reinforcement so the PCU team could ensure the intervention was understood, with one case involving a successful written solicitation regarding necessary changes in the prescription to the physician.

The interventions realized during the PTF included "suggestion to reconsider prescribed dose of a medicine" $(\mathrm{n}=4)$, "alert about not taking a prescribed medicine" $(\mathrm{n}=16)$, "correction of taking medicine process problems" $(\mathrm{n}=83)$, "alert of potential or manifested medication adverse effects" $(n=19)$ and "others" $(n=2)$.

After the completion of the interventions, it was possible to evaluate the outcome of 74 of them, which equates to $59.7 \%$ of the total 124 . Most of these 74 interventions $(n=66,89.2 \%)$ resulted in resolution or prevention of the problem presented by the patient / user, be it related to health or lack of information / education.

\section{DISCUSSION}

Our findings denoted a significant reduction in systolic blood pressure between the two-time points analyzed for the Intervention group, reaching a particular therapeutic objective (Sociedade Brasileira de Cardiologia, 2010). In turn, the "control" group showed no reduction in the systolic blood pressure. One can then infer that the pharmaceutical care was able to positively influence the reduction of systolic blood pressure values of the assisted patients/users, as inferred in previous studies (Lyra Junior et al, 2011; Firmino et al., 2012; Plaster, Melo, 2012; Zhao et al., 2012; Morgado, Rolo, Castelo-Branco, 2011).

A reduction from the initial value of diastolic blood pressure levels and consequently compliance with established therapeutic goal was observed, while in the "control" group, the same pattern was not observed. However, statistical tests did not confirm the hypothesis that the reduction was due to pharmaceutical intervention, which may be justified by the fact that the average initial levels were already near therapeutic target of 80 mmHg (Sociedade Brasileira de Cardiologia, 2010). This fact hinders the observation of sufficiently large difference between the values so that there was statistical significance, considering the number of study patients. Probably in a study with a larger number of participants or that included only hypertensive patients with both uncontrolled systolic and diastolic blood pressure levels a statistically significant difference would have been observed as showed in previous studies (Lyra Junior et al, 2011; Plaster, Melo, 2012; Morgado, Rolo, CasteloBranco, 2011). Although this fact was also reported before (Firmino et al., 2012; Al Mazroui et al., 2009).

There was a statistically significant reduction in cardiovascular risk in the "intervention" group while the "control" group showed no significant change in the average rate of cardiovascular risk after the study period. These results were shared by other studies that evaluated the effect of a pharmaceutical intervention 
on cardiovascular risk in other countries (Al Mazroui et al., 2009; Zhao et al., 2012; Amariles et al., 2012) and in Brazil (Lyra Junior et al., 2011; Firmino et al., 2012; Plaster, Melo, 2012; Martins, Aquino, 2013).

This way, the pharmaceutical care provided during the period of the study proved possible to establish a strategy to impact on cardiovascular risk management in hypertensive patients, being an intervention with immediate clinical benefit and preventive of escalations related to cardiovascular events compared to traditional health care offered to these patients.

The results regarding the changes in the average of the levels of total cholesterol and LDL and HDL fractions of the "intervention" group showed tendency to positive results, with variation of average values closer to therapeutic targets. In the "control" group, reductions in average of total cholesterol and its LDL fraction were also identified; however, the average of HDL had a minimal variation to below the initial value, unlike the group under PTF. Unfortunately, none of these changes achieved statistical significance, going against the results reported in a review (Eizerik, Manfroi, 2008) and more recent studies done in the country (Lyra Junior et al., 2011; Plaster, Melo, 2012).

Despite no statistical proof and the observation of a drop in the proportion of patients with controlled levels, it is noteworthy that, in the case of the average total cholesterol level in the "intervention" group, the average value achieved the therapeutic objective for this parameter (Sociedade Brasileira de Cardiologia, 2013) at the end of the study, indicating a potential clinical benefit related to the intervention performed in this work.

The results of the levels of triglycerides and glucose showed no conclusive results in the study groups. The studies with beneficial results on those indexes usually adopt a longer PTF than employed in our study, and that may be a determinant for such purpose (Lyra Junior et al. 2011; Al Mazroui et al., 2009; Chung et al., 2014; Collins et al., 2011).

The most frequently identified DRP during the PTF were the DRP 04, 03 and 05. These results are in line with DRP's profile identified in studies conducted in Brazil (Dall'Agnol, 2004; Netto, Melo, Silva, 2005; Alano, Corrêa, Galato, 2012), predominating, especially problems of therapeutic ineffectiveness. Many of these problems were related to the non-adherence to treatment by the patients, a behavior frequently identified among hypertensive patients due to the need for chronic therapy and the asymptomatic disease profile (Manfroi, Oliveira, 2006; Pucci et al., 2012).

The DRP 05 had relatively high incidence probably due to the average age of the study population to be approximately 60 because, according to studies (Dall'Agnol, 2004), this population is more susceptible to non-safety DRP, represented mainly by adverse events.

The identification of DRP 02 in our study was also observed in other studies conducted in Brazil (Dall'Agnol, 2004; Alano, Corrêa, Galato, 2012), but in a higher number of registered cases. In our study, this smaller number of records may be due to the limitation of the identification method for problems used, mainly depending on the selfreport of the participants who, when asked if they used non-prescription medicines, they responded that they only used prescribed drugs, with some exceptions. This fact may have led to an underestimation of self-medication, a habit known in the Brazilian population (Arrais et al., 1997; Sousa, Silva, Neto, 2008; Mastroianni et al., 2011).

Unfortunately, not every DRP identified had an intervention made with the purpose to solve or prevent it since some of those problems were related to eventual medicine shortages occurring in the Health Care Unit so the PCU team could not handle it. Also, not every intervention had its outcome evaluated because some of them were applied during the first interview of patients who were later allocated in the "control" group, which the PCU team was going to meet again just around five months later, considered late to associate any effect observed to the intervention suggested.

Nevertheless, in our study, several pharmaceutical interventions were used, aiming the prevention / resolution of DRP identified and, finally, approximately $90 \%$ of them had the expected outcome, i.e., they were able to solve or prevent the incident, a percentage similar to a study conducted in Santa Catarina (Alano, Corrêa, Galato, 2012). A few of the interventions did not result in solution/ prevention of the problem sometimes because the patient could not follow the orientation during his daily routine or because the other professional did not agree with the strategy suggested. In those cases, a new intervention was elaborated and suggested.

It is noticeable that the vast majority of the interventions had the patient as its target and focused on adherence problems resolution as it was the main cause for therapeutic ineffectiveness found in our study. This might suggest that most problems could be prevented if there was a health professional responsible for identifying and solving potential problems with taking medicines.

Furthermore, the authors highlight that the research was conducted in a previously established PCU in a Health Care Unit by CEATENF. This PCU was initiated in November 2008 and since then has been providing pharmaceutical care for hypertensive and diabetic patients as a routine. This study is a result of a real scenario 
pharmaceutical care service and is seen as a step further towards the complete establishment of pharmaceutical care practice in Health Care Units routine.

As a limitation of this study, it is important to highlight that the local people are still reluctant, at times, to understand the benefits of a guidance-oriented service on pharmacotherapy and issues related to the prevention of exacerbations of chronic diseases such as hypertension, which limited the number of patients willing to participate in the study. Moreover, the non-compliance, as a whole, of the other UAPS professionals, including pharmacists, to our survey resulted in a low number of patients referred to the study, were obstacles to the practice of pharmaceutical care previously reported (Oliveira et al., 2005). Finally, another limiting factor that hindered data collection compared to the rate of cardiovascular risk was that some participants did not go to LACT for blood collection and examinations required.

\section{CONCLUSIONS}

Given the results described and discussed, we conclude that the characteristics of the local population assisted by the primary health care show that it is necessary to institutionalize a guidance-oriented and monitoring service aimed to guarantee the effectiveness and safety of prescribed pharmacotherapy because there is still a lot of need for information on the subject to this population, which hinders the success of the treatment.

Our study suggests that the implementation of a pharmacotherapeutic follow-up of nine months for hypertensive patients has a positive impact on cardiovascular risk management compared to traditional health care provided by primary care. This reinforces that the exercise of clinical and health care activities directly targeting the hypertensive patient by the pharmacist, in partnership with the multidisciplinary team, is able to benefit blood pressure control thereof, especially when considering the systolic levels.

In addition, during the pharmacotherapeutic followup, several problems related to drug use were identified and prevented / resolved as pharmaceutical interventions were carried out comprising recommendations to the health care professionals, reinforcements about the prescribed therapy and educational interventions to the patients. Such pharmaceutical interventions were largely accepted in general. Thus, it emphasizes the importance of the provision of pharmaceutical care to hypertensive patients in relation to the improvement of the current health status and the prevention of future cardiovascular complications in different health care scenarios.

\section{ACKNOWLEDGEMENTS}

The authors would like to acknowledge the direction board of the UAPS Dr Anastácio Magalhães and the LACT for the support provided to make this study possible. The authors also are thankful to PIBIC/CNPq, UFC/PREX, INCT_if and CAPES for its financial support to the team involved in this project.

\section{REFERENCES}

AMARILES, P.; SABATER-HERNÁNDEZ, D.; GARCÍAJIMÉNEZ, E.; RODRÍGUEZ-CHAMORRO, M. Á.; PRATS-MÁS, R.; MARÍN-MAGÁN, F.; GALÁNCEBALLOS, J.A.; JIMÉNEZ-MARTÍN, J.; FAUS, M. J. Effectiveness of dader method for pharmaceutical care on control of blood pressure and total cholesterol in outpatients with cardiovascular disease or cardiovascular risk: EMDADER-CV randomized controlled trial. J. Manag. Care Pharm., v.18, n.4, p.311-323, 2012.

AMBIEL, I. S. S.; MASTROIANNI, P. D. C. Outcomes of pharmaceutical care in Brazil: a literature review. Rev. Ciênc. Farm. Básica Apl., v.34, n.4, p.475-480. 2013.

AGUIAR, P. M.; BALISA-ROCHA, B. J.; BRITO, G. C.; SILVA, W. B.; MACHADO, M.; LYRA Jr., D. P. Pharmaceutical care in hypertensive patients: a systematic literature review. Res. Social Adm. Pharm., v.8, n.5, p.383-396, 2012.

AL MAZROUI, N. R.; KAMAL, M. M.; GHABASH, N. M.; YACOUT, T. A.; KOLE, P. L.; MCELNAY, J. C. Influence of pharmaceutical care on health outcomes in patients with type 2 diabetes mellitus. Br. J. Clin. Pharmacol., v.67, n.5, p.547-557, 2009.

ALANO, G. M.; CORREAA, T. S.; GALATO, D. Indicadores do serviço de atenção farmacêutica (SAF) da universidade do sul de Santa Catarina. Ciênc. Saúde Coletiva, v.17, n.3, p.757-764, 2012.

ARRAIS, P. S. D.; COELHO, H. L. L.; BATISTA, M. C. D. S.; CARVALHO, M. L.; RIGHI, R. E.; ARNAU, J. M. Perfil da automedicação no Brasil. Rev. Saúde Pública, v.31, n.1, p.71-77, 1997.

BRASIL. Ministério da Saúde: DATASUS. Available at: $<$ http:// www.datasus.gov>. Accessed on: 17 Jan. 2013.

BRASIL. Ministério da Saúde: DATASUS. Available at: $<$ http:// www.datasus.gov>. Accessed on: 18 Mar. 2009. 
CASTRO, M. S.; CHEMELLO, C.; PILGER, D.; JUNGES, F.; BOHNEN, L.; ZIMMERMAN, L. M.; PAULINO, M. A.; JACOBS, U.; FERREIRA, M. B. C.; FUCHS, F. D. Contribuição da atenção farmacêutica no tratamento de pacientes hipertensos. Rev. Bras. Hipertens., v.13, n.3, p.198-202, 2006.

CHUNG, W. W.; CHUA, S. S.; LAI, P. S.; CHAN, S. P. Effects of a pharmaceutical care model on medication adherence and glycemic control of people with type 2 diabetes. Patient Prefer. Adherence, v.8, p.1185-1194. 2014.

COLLINS, C.; LIMONE, B. L.; SCHOLLE, J. M.; COLEMAN, C. I. Effect of pharmacist intervention on glycemic control in diabetes. Diabetes Res. Clin. Pract., v.92, n.2, p.145152,2011

COMITÉ DE CONSENSO. Segundo Consenso de Granada sobre Problemas Relacionados com Medicamentos. Ars Pharm., v.43, n.3/4, p.175-184, 2002.

DÁDER, M. J. F.; HERNÁNDEZ, D. S.; CASTRO, M. M. S. Método Dáder. manual de seguimento farmacoterapêutico. Alfenas: Editora Universidade Federal de Alfenas, 2014. $128 \mathrm{p}$.

DALL'AGNOL, R. S. A. Identificação e quantificação dos problemas relacionados com medicamentos em pacientes que buscam atendimento no serviço de emergência do HCPA. Porto Alegre, 2004. 112 f. [Dissertion of Master degree. Federal University of Rio Grande do Sul].

EIZERIK, D. P.; MANFROI, W. C. Eficácia da atenção farmacêutica em dislipidemia: revisão sistemática. Rev. HCPA, v.28, n.1, p.37-40, 2008.

FIRMINO, P. Y. M.; MARTINS, B. C. C.; ALVES, S. C. F.; VASCONCELOS, T. O.; LIMA, L. F.; OLIVEIRA, B. E.; VIEIRA, V. M. S. F.; PONCIANO, Â. M. S.; SILVA, L. I. M. M.; FONTELES, M. M. F. Avaliação do risco cardiovascular em pacientes hipertensos sob acompanhamento farmacoterapêutico em atenção primária à saúde. Rev. Bras. Farm. Hosp. Serv. Saúde, v.3, n.2, p.4246, 2012.

NOBRE, F. E. B. COELHO, E. B.; LOPES, P. C.; TUFIK, J. M. Hipertensão arterial sistêmica primária. Medicina (Ribeirão Preto), v.46, n.3, p.256-272. 2013.
IRONS, B. K.; MEYERROSE, G.; LAGUARDIA, S.; HAZEL, K.; SEIFERT, C. F. A collaborative cardiologist-pharmacist care model to improve hypertension management in patients with or at high risk for cardiovascular disease. Pharm. Pract., v.10, n.1, p.25-32, 2012.

LYRA JÚNIOR, D. P.; OBRELI NETO, P. R.; MARUSIC, S.; PILGER, D.; CRUCIOL-SOUZA, J. M.; GAETI, W. P.; CUMAN, R. K. N. Effect of a 36-month Pharmaceutical Care program on coronary heart disease risk in elderly diabetics and hypertensive patients. J. Pharm. Pharm. Sci., v.14, n.2, p.249-263, 2011.

MAHMOOD, S. S. D.; LEVY, D.; VASAN, R. S.; WANG, T. $\mathrm{J}$. The framingham heart study and the epidemiology of cardiovascular disease: a historical perspective. Lancet, v.383, p.999-1008, 2014

MANFROI, A.; OLIVEIRA, F. A. Dificuldades de adesão ao tratamento na hipertensão arterial sistêmica: considerações a partir de um estudo qualitativo em uma unidade de Atenção Primária à Saúde. Rev. Bras. Med. Fam. Com., v.2, n.7, p.165-176, 2006.

MARTINS, B. P. R.; AQUINO, A. T. D; PROVIN, M. P.; LIMA, D. M.; DEWULF, N. L. S.; AMARAL, R. G. Pharmaceutical Care for hypertensive patients provided within the Family Health Strategy in Goiânia, Goiás, Brazil. Braz. J. Pharm. Sci., v.49, n.3, P.609-618, 2013.

MASTROIANNI, P. D. C.; LUCCHETTA, R. C.; SARRA, J. R.; GALDURÓZ, J. C. F. Estoque doméstico e uso de medicamentos em uma população cadastrada na estratégia saúde da família no Brasil. Rev. Panam. Salud Publica, v.29, n.5, p.358-364, 2011.

MCLEAN, D. L.; MCALISTER, F. A.; JOHNSON, J. A.; KING, K. M.; MAKOWSKY, M. J.; JONES, C. A.; TSUYUKI, R. T.; SCRIP-HTN INVESTIGATORS. A randomized trial of the effect of community pharmacist and nurse care on improving blood pressure management in patients with Diabetes mellitus: . Arch. Intern. Med., v.168, n.21, p.23552361, 2008.

MORGADO, M.; ROLO, S.; CASTELO-BRANCO, M. Pharmacist intervention program to enhance hypertension control: a randomised controlled trial. Int. J. Clin. Pharm., v.33, n.1, p.132-140, 2011. 
NETTO, A. S. M.; MELO, F. B.; SILVA, W. B. Freqüência de problemas relacionados com medicamentos em pacientes que procuram o serviço de urgência de um hospital regional. Seguimiento Farmacoterapéutico, v.3, n.4, p.213-224, 2005.

OLIVEIRA, A. B.; OYAKAWA, C. N.; MIGUEL, M. D.; ZANIN, S. M. W.; MONTRUCCHIO, D. P. Obstáculos da atenção farmacêutica no Brasil. Braz. J. Pharm. Sci., v.41, n.4, p.409-413, 2005.

PASSOS, V. M. A.; ASSIS, T. D.; BARRETO, S. M. Hipertensão arterial no Brasil: estimativa de prevalência a partir de estudos de base populacional. Epidemiol. Serv. Saúde, v.15, n.1, p.35-45, 2006.

PLASTER, C. P.; MELO, D. T., et al. Reduction of cardiovascular risk in patients with metabolic syndrome in a community health center after a pharmaceutical care program of pharmacotherapy follow-up. Braz. J. Pharm. Sci., v.48, n.3, p.435-446, 2012.

PUCCI, N.; PEREIRA, M. R.; VINHOLES, D. B.; PUCCI, P.; CAMPOS, N. D. Conhecimento sobre hipertensão arterial sistêmica e adesão ao tratamento anti-hipertensivo em idosos. Rev. Bras. Cardiol., v.25, n.4, p.322-329, 2012.

ROUGHEAD, L.; SEMPLE, S.; VITRY, A. The value of pharmacist professional services in the community setting: a systematic review of the literature 1990-2002. Saudi Pharm. J., 2003.
SIMONI, C. R. Avaliação do impacto de métodos de Atenção Farmacêutica em pacientes hipertensos não-controlados. Porto Alegre, 2009. 184 p.[Dissertion of Master degree. Faculty of Pharmacy. Federal University of Rio Grande do Sul].

SOCIEDADE BRASILEIRA DE CARDIOLOGIA, SOCIODADE BRASILEIRA DE HIPERTENSÃO; SOCIEDADE BRASILEIRA DE NEFROLOGIA. VI Diretrizes Brasileira de Hipertensão Arterial. São Paulo, 2010.

SOCIEDADE BRASILEIRADE CARDIOLOGIA. V Diretrizes brasileiras sobre dislipidemia e prevenção de aterosclerose. Arq. Bras. Cardiol., v.101, n.4, p.1-35, 2013.

SOUSA, H. W. O.; SILVA, J. L.; NETO, M. S. A importância do profissional farmacêutico no combate à automedicação no Brasil. Rev. Eletr. Farm., v.5, n.1, p.67-72, 2008.

ZHAO, P.; WANG, C.; QIN, L.; YUAN, M.; XIAO, Q.; GUO, Y.-H.; WEN, A.-D. Effect of clinical pharmacist's pharmaceutical care intervention to control hypertensive outpatients in China. Afr. J. Pharm. Pharmacol., v.6, n.1, p.48-56, 2012.

Received for publication on $05^{\text {th }}$ September 2014 Accepted for publication on $09^{\text {th }}$ June 2015 
